\title{
Xolair $^{\circledast}$ (omalizumab) enrollment in a tertiary care allergy and asthma clinic in Canada
}

\author{
Jodi Cameron ${ }^{1 *}$, Jennifer Forgie ${ }^{1}$, Alicia Ring ${ }^{1}$, Stephanie Santucci ${ }^{1}$, Caroline Rizk ${ }^{2}$, Hoang Pham ${ }^{3}$, John O'Quinn ${ }^{1}$, \\ William H Yang ${ }^{1,3}$
}

From Canadian Society of Allergy and Clinical Immunology Annual Scientific Meeting 2014

Ottawa, ON, Canada. 23-26 October 2014

\section{Background}

Xolair ${ }^{\circledR}$ (omalizumab) has been approved in Canada since 2004 for the treatment of moderate to severe persistent allergic asthma in patients 12 years of age. The use of omalizumab in severe persistent allergic asthma may lead to decrease health care utilization through emergency room (ER) visits, hospitalizations, visits to health care providers, as well as, decrease the use of corticosteroids and improve the overall quality of life (QoL).

\section{Methods}

Data collected from patient enrollment and QoL questionnaires completed at specific intervals during treatment with omalizumab at our large tertiary care clinic from 2004 to 2014 was analyzed.

\section{Results}

A steady number of patients were enrolled each year since 2004, showing its greatest increase in enrollment numbers since 2012. Our data indicates that the majority of patients improved with significantly less asthma exacerbation, less ER visits and hospitalizations, less use of inhaled and oral corticosteroids and better QoL.

\section{Conclusion}

Omalizumab is effective in the treatment of moderate and severe allergic asthma. It improves QoL and reduces asthma exacerbations, ER visits and hospitalizations, and use of inhaled and oral corticosteroids.

\section{Authors' details}

${ }^{1}$ Allergy and Asthma Research Centre, Ottawa, ON, Canada. ${ }^{2}$ Department of Clinical Immunology and Allergy, McGill University, Montreal, Canada.

${ }^{3}$ University of Ottawa Medical School, Ottawa, ON, Canada.

1Allergy and Asthma Research Centre, Ottawa, ON, Canada

Full list of author information is available at the end of the article
Published: 18 December 2014

doi:10.1186/1710-1492-10-S2-A5

Cite this article as: Cameron et al: Xolair (omalizumab) enrollment in a tertiary care allergy and asthma clinic in Canada. Allergy, Asthma and

Clinical Immunology 2014 10(Suppl 2):A5.
Submit your next manuscript to BioMed Central and take full advantage of:

- Convenient online submission

- Thorough peer review

- No space constraints or color figure charges

- Immediate publication on acceptance

- Inclusion in PubMed, CAS, Scopus and Google Scholar

- Research which is freely available for redistribution
() Biomed Central
C Biomed Central

(c) 2014 Cameron et al; licensee BioMed Central Ltd. This is an Open Access article distributed under the terms of the Creative Commons Attribution License (http://creativecommons.org/licenses/by/4.0), which permits unrestricted use, distribution, and reproduction in any medium, provided the original work is properly cited. The Creative Commons Public Domain Dedication waiver (http://creativecommons.org/publicdomain/zero/1.0/) applies to the data made available in this article, unless otherwise stated. 